\title{
ISOLATION, QUANTIFICATION, AND IDENTIFICATION OF ROSMARINIC ACID, GAS CHROMATOGRAPHY-MASS SPECTROMETRY ANALYSIS OF ESSENTIAL OIL, CYTOTOXIC EFFECT, AND ANTIMICROBIAL INVESTIGATION OF ROSMARINUS OFFICINALIS LEAVES.
}

\author{
AMANI A TAWFEEQ ${ }^{1 *}$, MONTHER F MAHDI ${ }^{2}$, IBRAHIM S ABAAS ${ }^{1}$, ALI HUSSEIN ALWAN ${ }^{3}$ \\ ${ }^{1}$ Department of Pharmacognosy and Medicinal Plants, College of Pharmacy, Al-Mustansiriya University, Baghdad, Iraq. ${ }^{2}$ Department of \\ Pharmaceutical Chemistry, College of Pharmacy, Al-Mustansiriya University, Baghdad, Iraq. ${ }^{3}$ Department of Biology, College of Science, \\ Al-Mustansiriyah University, Baghdad, Iraq. Email: phamjmoni87@gmail.com
}

Received: 05 December 2017, Revised and Accepted: 19 February 2018

\section{ABSTRACT}

Objective: Rosmarinus officinalis $\mathrm{L}$. is an aromatic perennial herb with fragrant evergreen needle-like leaves, and it is member species of Lamiaceae family raised from Mediterranean region. The aims of the study were isolation, quantification, and identification of rosmarinic acid of $R$. officinalis leaves and essential oil analysis using various chromatographic and spectroscopic methods, and also cytotoxic and antibacterial investigation against different species of bacteria.

Methods: It was isolated by preparative HPLC and preparative TLC, and then it was determined by HPTLC. The identification and the structural elucidation of isolated rosmarinic acid were performed by H-nuclear magnetic resonance, electrospray ionization mass spectrometry (MS), infrared, and ultraviolet. Essential oil was analyzed by Gas Chromatography/Mass.

Results: Results highlighted that rosmarinic acid content was $0.9 \%$ and the oil content was $1.8 \%$, and $R$. officinalis chemotypes of Iraqi rosemary oil were camphor $23.04 \%, 1$, 8-cineole $14.01 \%$, and terpinen-4-ol 13.8\%. The rosemary chemotype characterized as a high concentration of terpinen4-ol and good inhibition effect of rosemary methanolic extract against different species bacteria: Enterococcus faecalis, Staphylococcus saprophyticus, Acinetobacter baumannii, and Proteus mirabilis.

Conclusions: The plant has a good content of rosemary phytochemicals and antibacterial effect, so the plantation of rosemary in Iraq has been successes. These isolated compounds are a suitable candidate for further clinical and pharmacological study.

Keywords: Antimicrobial, Rosmarinus officinalis, Rosmarinic acid, Essential oil, Terpinen-4-ol, Isolation.

(c) 2018 The Authors. Published by Innovare Academic Sciences Pvt Ltd. This is an open access article under the CC BY license (http://creativecommons. org/licenses/by/4. 0/) DOI: http://dx.doi.org/10.22159/ajpcr.2018.v11i6.24134

\section{INTRODUCTION}

Ever since ancient times, the humankind was a turning point in the recognition, use, and development of methods for structural elucidation and isolation of plant-derived drugs that played an important role in traditional and modern drug [1]. Rosmarinus officinalis $\mathrm{L}$. is an aromatic, perennial herb with fragrant evergreen needle-like leaves, and also, it is member species of Lamiaceae family raised from Mediterranean region [2,3]. R. officinalis L. be composed of monoterpenes, primarily phenolic acids, rosmarinic acid, flavonoids, diterpenoids, and triterpenes [4]. Rosmarinic acid $\left(\mathrm{C}_{18} \mathrm{H}_{16} \mathrm{O}_{8}\right)$ is $\alpha$-0caffeoyl-3,4-dihydroxy-phenyl lactic acid, and mainly it is presented in different species of Labiatae family $[5,6]$.

According to a clinical study, examined the pharmacokinetic parameters of RA, after absorption to blood circulation, the compound was metabolized and degraded to give conjugated and/or methylated forms of caffeic acid (CA), m-coumaric acid, and ferulic acid before being eliminated or excreted gradually in the urine [7].

Literature review revealed that rosmarinic acid and its derivatives have been shown to have biological activities, which included: antiinflammatory [8], anti hyperglycemic [9],anti allergic [10], anti bacterial activity [11], anti-oxidant [12], in addition those have beneficial effect in Parkinson's disease [13], neuroprotective effect[14], and also have nephroprotective activity belong to their antioxidant potency through enhancing the activity of antioxidant enzymes and enhancing the glutathione content [15]. R. officinalis contains a great quantity of essential oil that formed from chemical components; these are hydrocarbon monoterpenes (e.g., camphene, pinene, limonene, and myrcene), sesquiterpenes (e.g., caryophyllene), and oxygen deravatives such as alcohols (e.g., borneol, linalool, and terpineol), ketones (e.g., camphor and verbenone), oxide (e.g., 1, 8-cineole), esters (e.g., bornyl acetate), and others [16]. Monoterpene hydrocarbon $\left(\mathrm{C}_{10} \mathrm{H}_{16}\right)$ chemically is ten carbon atoms (two isoprene units) with $\mathrm{C}=\mathrm{C}$ double bonds joined head-to-head [17].

The resistant of pathogens to antimicrobial agent increased and spread, and also the efficiency of the antibiotic drugs are diminished; all these give rise to affect the human health. Hence, the use of traditionalalternative medicine as a source to treat infectious diseases has been accomplished since the origin of humankind [18]. Available information indicates that hydroalcoholic extract of rosemary was assayed against different strains of bacteria $[19,20]$.

In this present study, we report essential oil yield content and gas chromatography-mass spectrometry (GC-MS) analysis of its constituents extracted from leaves of rosemary plant cultivated in Baghdad, Iraq, also we report identification, estimation of rosmarinic acid, and isolation, quantification, and the structure elucidation were done by nuclear magnetic resonance (NMR), infrared (IR), and MS spectroscopy.

To the best of our knowledge, This study is the first work studied the qualitative- quantitative analysis and isolation with structural elucidation of rosmarinic acid of $R$. officinalis recently grown in Iraq, 
according to results of this study the cultivation of plant was success in Iraq.

\section{METHODS}

\section{General procedures}

Ultraviolet (UV) spectra were recorded in MEOH using CAMAG system, IR spectra in KBR disk on Fourier-transform IR (FTIR) (Jasco-6100), H-NMR spectrum was measured on BRUKER AVANCE II $400 \mathrm{MHz}$ apparatus, LC/MS/MS spectra carried out on SHIMADZU (LCMS 8040) model triple-quadruple MS spectrometer apparatus, also GC-MS analysis was performed on Shimadazu-QP 2010 ultra, the capillary column $(30 \mathrm{~m} \times 0.25 \mathrm{~mm}$ internal diameter, film thickness $0.25 \mu \mathrm{m}$ ) at a flow rate $1.53 \mathrm{~mL} / \mathrm{min}$, high-performance liquid chromatography (HPLC) analysis was performed using Shimadzu 10AV-LC equipped with binary delivery pump model LC10A Shimadzu, the eluted peaks were monitored by UV-Vis 10A-SPD spectrophotometer, high-performance thin-layer chromatography (HPTLC) analysis was carried out using CAMAG system (Switzerland), pre-coated silica gel GF254(aluminum TLC) from Merck co., and the standard rosmarinic acid from Sigma-Aldrich chemicals Co. All the solvents were from Sigma-Aldrich chemicals Co and Merk chemical company.

\section{Plant material}

Leaves of $R$. officinalis plant were collected from the garden of medicinal plants, College of Pharmacy/Mustansiriyah University in Baghdad, Iraq. Authentication of plant carried out by the National Herbarium in Botany Directorate at Abu-Ghraib, Baghdad, Iraq.

\section{Extraction of essential oil}

The hydrodistillation of $200 \mathrm{~g}$ of air-dried rosemary leaves by Clevenger apparatus. The rosemary oil was kept at $-4^{\circ} \mathrm{C}$ in an airtight container.

\section{Preparation of aqueous methanolic extract}

The test solution for an extract of rosemary leaves was prepared for detection of rosmarinic acid. The extracts prepare by mixing $1 \mathrm{~g}$ of powdered drug with $10 \mathrm{ml}$ of $90 \%$ methanol and boiled in a water bath under reflux condenser for $30 \mathrm{~min}$. Then, the sample was used for the determination or identification of rosmarinic acid in comparison with rosmarinic acid standard which is prepared by dissolving $1 \mathrm{mg} / 10 \mathrm{ml}$ of methanol solvent and stored in freezer at $-15^{\circ} \mathrm{C}$ until used as a reference solution of $0.1 \mathrm{mg} / \mathrm{mL}$

\section{Chromatographic analysis for the detection of rosmarinic acid \\ $T L C$}

TLC analysis of extract in comparison with rosmarinic acid standard was done by development with formic acid:acetone:methylene chloride (0.85:2.5:8.5) as a mobile phase [21].

HPTLC analysis was conducted to detect the presence of rosmarinic acid. HPTLC analysis was performed by using HPTLC silica gel 60 GF 254s $(10 \times 20 \mathrm{~cm})$, the layer thickness was $0.5 \mathrm{~mm}$. The standard rosmarinic acid $2 \mu \mathrm{L}$ and $3 \mu \mathrm{L}$ from each extract $\left(\mathrm{E}_{\mathrm{b}}\right.$ and $\mathrm{E}_{\mathrm{k}}$ ) were applied automatically on the plate by CAMAG Linomat 5 . The plate was automatically submerged into an automatic developing chamber (ADC2 CAMAG) using solvent system (hexane:ethyl acetate:formic acid, 20:19:1, v/v/v), with migration distance about $7.5 \mathrm{~cm}$. The plates were air-dried after development and scanned under UV (366 and $245 \mathrm{~nm}$ ) using CAMAG TLC scanner 4. The data were processed using win CATS software.

\section{HPLC}

HPLC analysis was performed for analysis and estimation of RA in hydroalcoholic rosemary extract. The HPLC analysis was carried out by prominence HPLC with a degasser (DGU-20A) and the separation was performed in reverse-phase Hypersil ODS-C18 column (250 $\mathrm{mm} \times 4.6 \mathrm{~mm}$ i.d); sample was filtered through $0.45 \mu \mathrm{m}$ pore size membrane. Isocratic system was used with mobile phase consisting of $80 \%$ methanol as solvent (a) and $20 \%$ (water with $0.1 \%$ acetic acid) as solvent (b). A flow rate was set at $1 \mathrm{ml} / \mathrm{min}$ for $10 \mathrm{~min}$, detected by UV at $320 \mathrm{~nm}$ [22].

\section{Isolation and purification of rosmarinic acid}

The powdered leaves of rosemary were defatted, then after extracted twice with $2 \mathrm{l}$ of water at $80^{\circ} \mathrm{C}$ for $50 \mathrm{~min}$ with stirring, acidifying with $25 \% \mathrm{HCl}$, partitioning (3 times) of each $100 \mathrm{ml}$ of resulting solution with $35 \mathrm{ml}$ of diethyl ether was performed to get rosmarinic acid extract.

The rosmarinic acid extract was dissolved in methanol and subjected to preparative HPLC using RP- $\mathrm{C}_{18}$ column with a mobile phase (methanol: $0.1 \%$ acetic acid) as isocratic mixture (80:20), flow rate was $10 \mathrm{ml} / \mathrm{min}$, detected at $320 \mathrm{~nm}$, and run time was $10 \mathrm{~min}$. Rosmarinic acid peak was collected off the column in comparison with a retention time of rosmarinic acid standard.

Furthermore, preparative TLC was carried out for further purification technique and eluted with formic acid:acetone:methylene chloride $(0.85: 2.5: 8.5)$ as a mobile phase, and the separated bands were visualized under UV light at $254 \mathrm{~nm}$. The band at $\mathrm{R}_{\mathrm{f}}=0.51$ was scrapped off in comparison with the standard, then eluted with methanol and recrystallization from water to gets purified compound, and then weighted the resulted powder.

\section{Identification of isolated rosmarinic acid}

\section{Identification by HPTLC}

HPTLC analysis of isolated rosmarinic acid was performed, by application of standard rosmarinic acid $(5 \mu \mathrm{L})$, and isolated compound by preparative chromatography $(5 \mu \mathrm{L})$ was applied automatically on the plate by CAMAG Linomat 5 and developed with toluene: ethyl acetate:formic acid 5:4:1 as a solvent system, scanned under UV (254 and $366 \mathrm{~nm}$ ) using CAMAG TLC scanner 4 [23]. $\mathrm{R}_{\mathrm{f}}$ value was 0.25 .

\section{Spectrometric analysis}

Chemical structure elucidation was obtained by IR, UV, NMR, and electrospray ionization MS (ESI-MS), liquid mass detection was equipped with an ESI source working in negative ion mode, and LC separation was carried out on phenomenex C18 guard column (150 mm $\times 4.6 \mathrm{~mm}$ i.d, $5 \mu$ ).

\section{GC-MS}

GC-MS analysis was carried out to identify the essential oil from leaves of Bagdad plants with GC-MS Shimadzu-QP-2010 ULTRA. The capillary column $(30 \mathrm{~m} \times 0.25 \mathrm{~mm}$ internal diameter and film thickness $0.25 \mu \mathrm{m})$ at a flow rate $1.53 \mathrm{~mL} / \mathrm{min}$, helium carrier gas was used, injection mode was split, and injection temperature was $240^{\circ} \mathrm{C}$; the oven temperature was programmed at $70^{\circ} \mathrm{C}$ for $(3 \mathrm{~min})$, then raised to $150^{\circ} \mathrm{C}$ with an hold time $2.00 \mathrm{~min}$, and then increased to $240^{\circ} \mathrm{C}$, and the ionization mode was electronic impact mode (SEI) at 70e. Identification of the components of the oil was performed by comparing their mass spectra with database library of the National Institute of Standards and Technology (NIST08) and also comparing with the available references.

\section{Cytotoxicity}

The toxic effect of the tested compounds on mammalian cells was done in vitro on human red blood cells using well plate method; blood agar media were prepared according to the instructions of the manufacturing companies and sterilized in autoclave. Then, $100 \mu \mathrm{l}$ of extract was poured in a well, plates were incubated for $24 \mathrm{~h}$ at $37^{\circ} \mathrm{C}$, and positive result was indicated by inhibition zone around the wells.

\section{Investigation of the antibacterial activity}

Preliminary antibacterial was performed for methanolic extract of rosemary leaves.

\section{Preparation of the extract}

Crude methanolic extract of rosemary leaves was prepared by the extraction of $20 \mathrm{~g}$ from powdered leaves with $150 \mathrm{ml}$ of methanol in Soxhlet apparatus. The yielded methanolic extract was dried by rotary 
evaporator. The powdered extracts were kept in sterilized Petri-dishes at a refrigerator, and they were wrapped with parafilm and aluminum covers. The stock solution $100 \mathrm{mg} / \mathrm{mL}$ was prepared by dissolving $100 \mathrm{mg}$ from alcoholic extract of plant in $1 \mathrm{~mL}$ of dimethyl sulfoxide (DMSO). The dilution serials of 50.0, 25.0, and $12.5 \mathrm{ml}$ were prepared for antibacterial assay.

\section{Antibacterial Assay}

Four species of bacteria were used to assay the antibacterial activity of crude extract in this study, two of them are Gram-positive (Enterococcus faecalis and Staphylococcus saprophyticus) and the other two were Gram-negative (Acinetobacter baumannii and Proteus mirabilis).

The antibacterial activity of alcoholic extract was determined by agar/ well diffusion assay and carried out using pure culture for all species of bacteria. Inoculum of bacteria was first subcultured in Brain Heart Infusion Broth and incubated at $37^{\circ} \mathrm{C}$ for $18-24 \mathrm{~h}$. After incubation, a loopful of each species was transferred to tube containing $3 \mathrm{ml}$ of normal saline and vortex well. A concentration of $1.5 \times 10^{8}$ colonyforming unit/ $\mathrm{mL}$ was obtained using McFarland turbidity standard of each bacteria inoculated using glass spreader on the surface of Mueller-Hinton Agar (MHA) plates previously prepared. The plate was allowed to dry and punched wells (five) in diameter of $6 \mathrm{~mm}$ into agar. Subsequently, in each agar plate of tested bacteria, five wells were made and $100 \mu \mathrm{l}$ of dilutions of the extracts $(100,50.0,25.0$, and $12.5 \mathrm{mg} / \mathrm{mL})$ introduced into wells on MHA plate. DMSO was used as the negative controller, and then, the plates were kept at $37^{\circ} \mathrm{C}$ for $24 \mathrm{~h}$.

\section{RESULTS}

Chromatographic analysis for detection of rosmarinic acid

The extract of rosemary leaves was analyzed by HPLC and HPTLC.

\section{TLC}

The result showed the best separation of compounds in the aqueous methanolic extract and a fluorescent blue spot of rosmarinic acid was showed under $366 \mathrm{~nm}$ of $\mathrm{UV}$ light with $\mathrm{R}_{\mathrm{f}}$ value 0.5 in comparison with standard rosmarinic acid.

HPTLC chromatogram of the rosemary extract showed well-defined peak number 6 at maximum $\mathrm{Rf}$ of 0.30 that represents $37.60 \%$ of the total extract compositions as shown in Fig. 1. With reference to $R_{\mathrm{f}}$ value of standard rosmarinic acid, the observed peak identified as rosmarinic acid.

\section{HPLC}

HPLC analysis showed rosmarinic acid peak at $\mathrm{R}_{\mathrm{t}} 3.057$ min representing $46.607 \%$ of the total compositions of rosemary extract compared with a retention time of rosmarinic acid standard (2.99 min) as shown in Fig. 2.

\section{Total rosmarinic acid content}

The amount of RA was isolated and quantified about $0.9 \% \mathrm{w} / \mathrm{v}$ in rosemary leaves extract, (Fig. 3) shows the separation bands of rosmarinic acid extract by prep. TLC the amount of RA was $0.9 \% \mathrm{w} / \mathrm{v}$ in rosemary leaves.

\section{Spectrometric analysis}

The isolated compound obtained as off-white powder with $\mathrm{R}_{\mathrm{f}}=0.5$, chemical investigation of this compound indicated the structure of rosmarinic acid (Fig. 4), and ESI-MS under negative ion mode together with IR, ${ }^{1} \mathrm{H}-\mathrm{NMR}$, and spectral data confirmed the molecular formula to be $\mathrm{C}_{18} \mathrm{H}_{16} \mathrm{O}_{8}$. The maximum UV absorption of characteristics of rosmarinic acid was $328 \mathrm{~nm}$ in comparison with standard $329 \mathrm{~nm}$, and ESI-MS showed the molecular ion peak [M-1] ${ }^{-}$at $\mathrm{m} / \mathrm{z}=359$ (Fig. 5) and base peak at $m / z=161$, Also appear other peaks at $m / z 197$ and 179 of two main constituents of RA: 2-hydroxyl derivative of hydro CA and CA, respectively, this pattern of fragmentation compared with those data reported previously [24].

The IR spectrum $(\mathrm{KBr})$ showed broad absorption band at 3181/cm $(\mathrm{OH}$ of carboxylic acid, broad), in addition to other bands at $1718 / \mathrm{cm}(\mathrm{C}=0$ of carboxylic acid), 1683/cm ( $\mathrm{C}=0$ of conjugated with double bond), 1514 and $1481 / \mathrm{cm}$ (stretching of aromatic ring), and 1400-1350/cm C-O-C stretching as shown in Fig. $6 .{ }^{1} \mathrm{H}-\mathrm{NMR}$ spectral data (DMSO- $\mathrm{d}_{6}$, $400 \mathrm{MHz}$ ) are listed in Table 1.

\section{GC-MS analysis of essential oil}

The pale-yellow oil isolated from rosemary leaves was $1.8 \% \mathrm{w} / \mathrm{v}$. The GC-MS analysis has been shown 12 identified components from 19 components representing $91.36 \%$ of the total oil. Oxygenated monoterpenes were found to be the major group of these components. Furthermore, the dominant constituents were camphor (23.04\%), 1, 8-cineole (14.01\%), and terpinen-4-ol (13.8\%) respectively, and also the minor common components of volatile oil are verbenone $(11.47 \%)$, $\beta$-terpineol $(10.8 \%)$, bornyl acetate $(6.96 \%)$, and borneol $(3.78 \%)$. The D-limonene and camphene have low percentage about $0.42 \%$ and $0.36 \%$, respectively, as shown in Table 2 . The UN identified compounds represent the remaining compound.

\section{Anti-bacterial assay}

Minimum inhibitory concentration values determined by the well diffusion method showed values ranging from 12.5 to $100 \mathrm{mg} / \mathrm{ml}$ for R. officinalis extract according to different species of bacteria (Table 3).

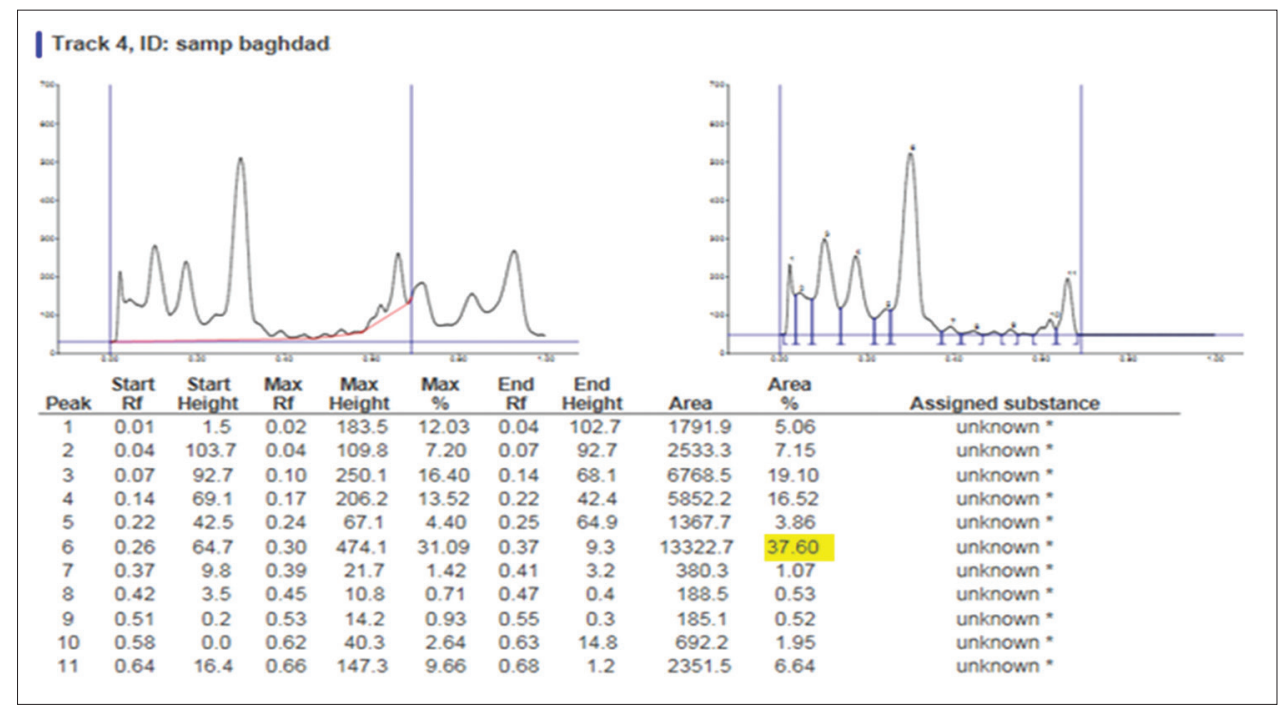

Fig. 1: High-performance thin-layer chromatography chromatogram of extract from leaves of Rosmarinus officinalis cultivated in Iraq 


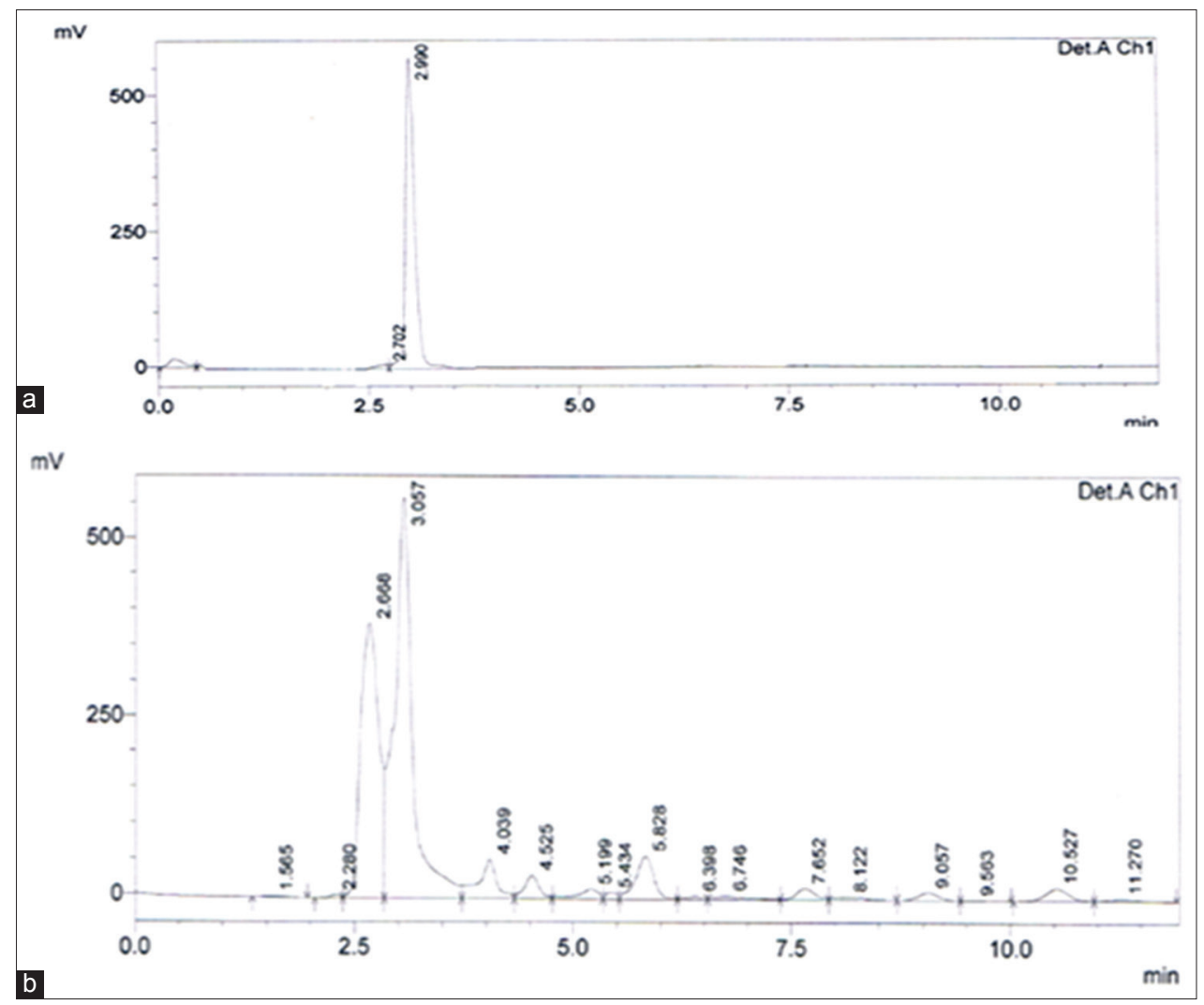

Fig. 2: The high-performance liquid chromatography analysis of $90 \%$ methanolic extract of rosemary leaves, (a) peak of standard rosmarinic acid was detected at $2.99 \mathrm{~min}$ (b) rosmarinic acid in hydrolcholic extract was detected at $2.66 \mathrm{~min}$

Table 1: H-NMR data and their interpretation for rosmarinic acid compound

\begin{tabular}{llll}
\hline No. of group & Chemical Shift ppm & No. of proton & Interpretation \\
\hline A & 2.8 & $1 \mathrm{H}$ & Multiplate of methylene \\
$\mathrm{a}^{\prime}$ & 3.02 & $1 \mathrm{H}$ & Group \\
B & 5.05 & $1 \mathrm{H}$ & Triplet of proton at chiral center \\
C & $1 \mathrm{H}$ & Doublet of olefinic proton \\
D & 6.28 & $3 \mathrm{H}$ & Doublet of protons at aromatic ring B \\
E & $6.52-6.65$ & $\mathrm{H}$ & Doublet of protons ortho to protons of -OH group at aromatic ring A \\
F & $6.76-6.78$ & $1 \mathrm{H}$ & Doublet of aromatic ring A \\
G & 7.05 & $1 \mathrm{H}$ & Doublet of vicinal proton \\
h, h' & $7.45-7.49$ & $2 \mathrm{H}$ & Broad singlet protons of aromatic ring A \\
i, i' & $8.73-8.79$ & $2 \mathrm{H}$ & Broad singlet protons of aromatic ring B \\
J & $9.51-9.64$ & $1 \mathrm{H}$ & Singlet of carboxylic acid proton \\
\hline
\end{tabular}

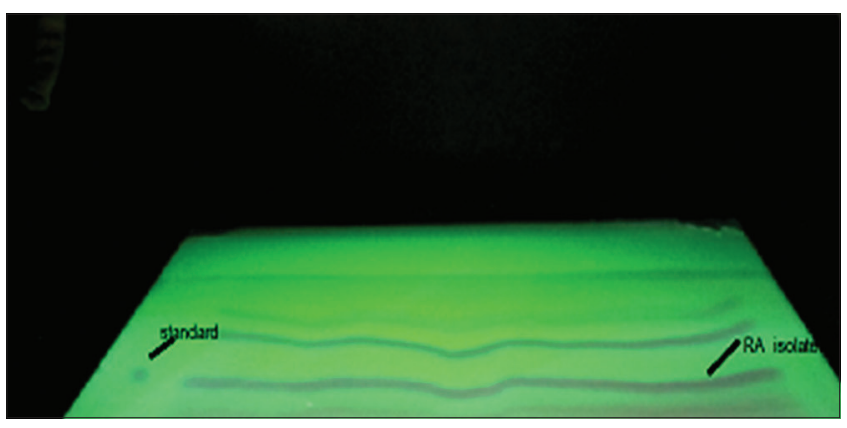

Fig. 3: Preparative thin-layer chromatography for isolation of rosmarinic acid extract under ultraviolet light at $254 \mathrm{~nm}$

\section{DISCUSSION}

From results highlights, the high amount of rosmarinic acid was $0.9 \%$ in leaves of Iraqi $R$. officinalis and this quantity of RA is considered higher

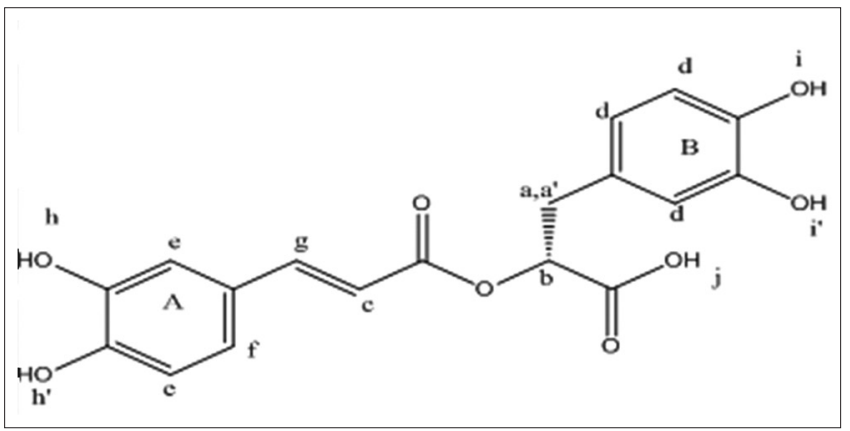

Fig. 4: Chemical structure of rosmarinic acid

than RA in some other different geographical location such as Romania, Turkey, and Iran $(0.133 \%, 0.31 \%$, and $0.72 \%$, respectively) and $<1.1 \%$ of rosmarinic acid of rosemary plant from trade of UK [25-27]. The variability in RA content of a plant is known to depend on any environmental factors including harvested time, soil, climatic conditions, and other factors [28]. 


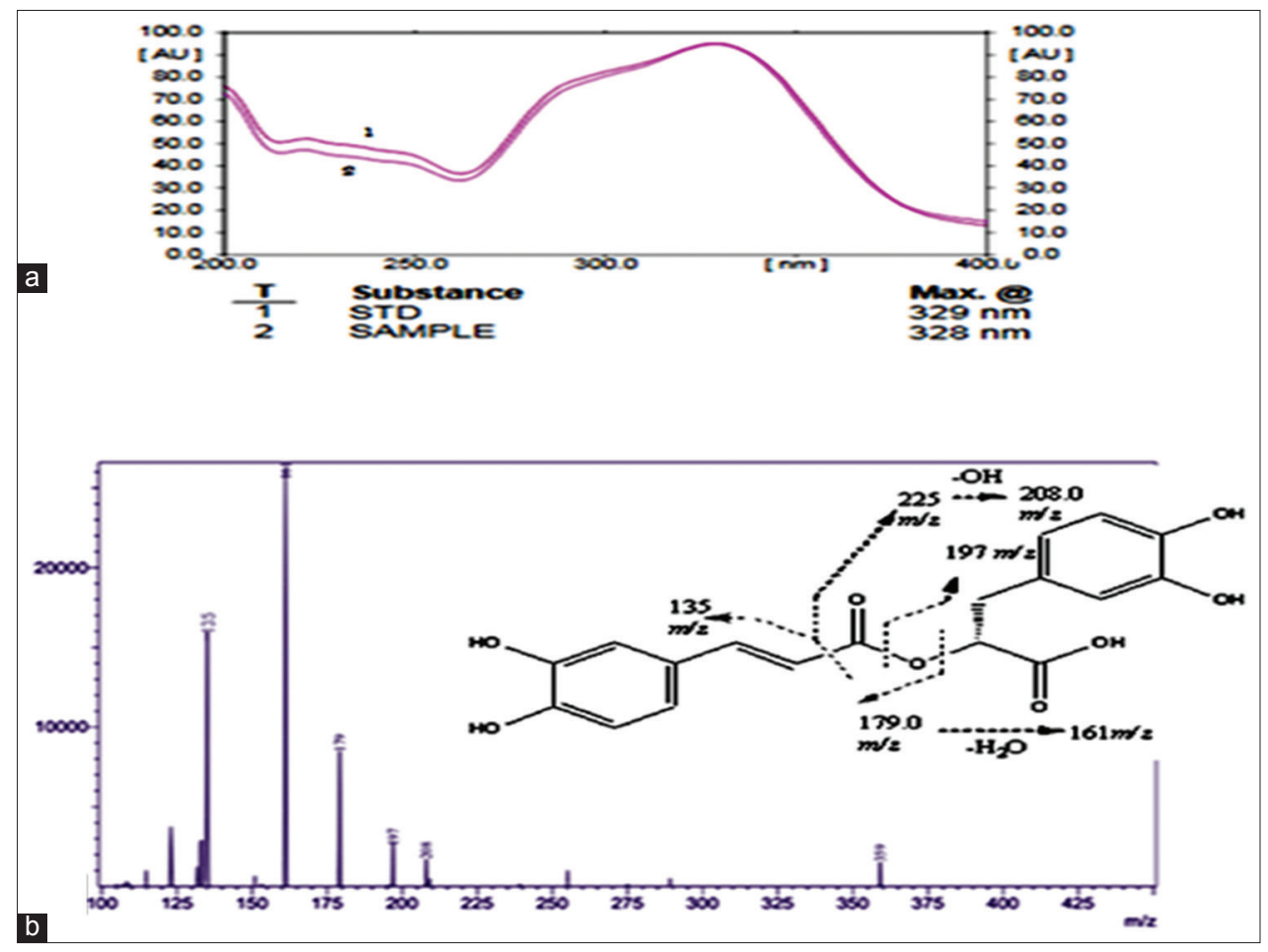

Fig. 5: Spectral analysis of rosmarinic acid (a) ultraviolat spectra of rosmarinic acid detected at $328 \mathrm{~nm}$ in comparison with standard was detected at $329 \mathrm{~nm}$. (b) Mass spectrum obtained after mass spectrometry/mass spectrometry fragmentation of deprotonated molecular ion at M/Z 359 (M-1)

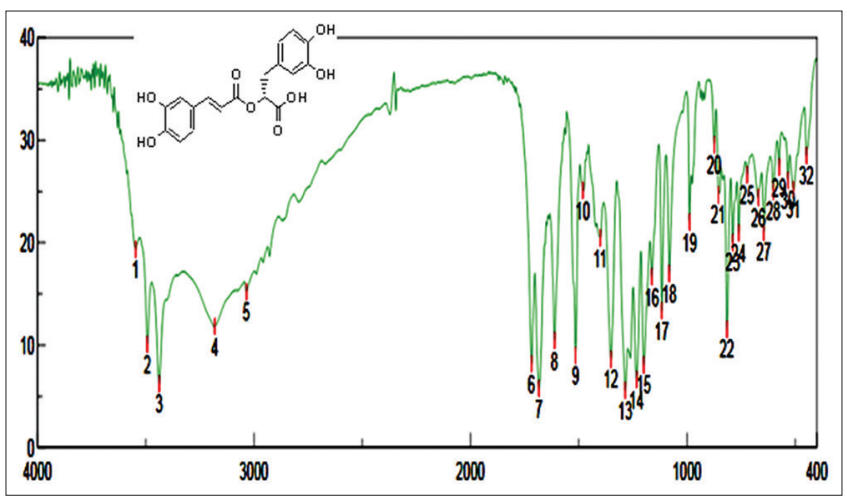

Fig. 6: Fourier-transform-infrared spectroscopy for rosmarinic acid

Spectral analysis of RA compound indicates that compound is rosmarinic acid, ${ }^{1} \mathrm{H}-\mathrm{NMR}$ spectrum showed the signals for rosmarinic acid (isolated compound), the aromatic protons showed at 7.063$6.52 \mathrm{ppm}$, and The chemical shift of two diasteriotopic protons of methylene group presence at 3.02, 2.8, it showed doublet of doublet splitting. The spectral data were agreement with previously reported literature for the same compounds $[29,30]$.

From the results mentioned above, that essential oil content was $1.8 \%$ isolated from leaves of Iraqi $R$. officinalis. Furthermore, the leaves of Iraqi $R$. officinalis chemotypes were camphor $23.04 \%$, 1, 8-cineole $14.01 \%$, and terpinen-4-ol $13.8 \%$. This chemotype characterized with good concentrations of components and high concentration of terpinen- 4-ol than some other countries in comparison with chemical point view from the previous study of oil in varying geographical environments (Table 4) [31-37].

In general, the diversity in quantity of oil contents, percentage of components, and chemotypes of $R$. officinalis in different locations have
Table 2: The chemical compositions of essential oil of R. officinalis leaves, analyzed by GC-MS

\begin{tabular}{lllll}
\hline Peak no. & *R.T & Area\% & $\begin{array}{l}\text { Molecular } \\
\text { ion (m/z) }\end{array}$ & $\begin{array}{l}\text { Name of } \\
\text { compound }\end{array}$ \\
\hline 1 & 4.82 & 0.42 & 136 & D-limonene \\
2 & 5.19 & 14.01 & 154 & 1,8-cineole \\
5 & 9.37 & 23.04 & 152 & Camphor \\
6 & 9.66 & 10.8 & 136 & $\beta$ - terpineol \\
7 & 10.18 & 6.96 & 154 & Bornyl acetate \\
8 & 10.43 & 3.78 & 139 & Borneol \\
9 & 11.12 & 0.45 & 137 & Cis-verbenol \\
11 & 11.81 & 13.80 & 154 & Terpinen-4-ol \\
12 & 11.98 & 11.47 & 150 & Verbenone \\
14 & 12.29 & 0.36 & 136 & Camphene \\
15 & 12.73 & 0.48 & 152 & Camphenol \\
\hline
\end{tabular}

Total identified compounds: $91.36 \% .{ }^{*}$ RT: Retention time. R. officinalis: Rosmarinus officinalis, GC-MS: Gas chromatography-mass spectrometry

Table 3: Antibacterial activity of $R$. officinalis extracts with different bacterial species measured in millimeter

\begin{tabular}{llllll}
\hline Bacterial species & \multicolumn{3}{l}{$\begin{array}{l}\text { Concentrations of extracts } \\
\text { mg/mL }\end{array}$} & MIC $\mathbf{~ m g} / \mathbf{m L}$ \\
\cline { 2 - 5 } & $\mathbf{1 0 0}$ & $\mathbf{5 0}$ & $\mathbf{2 5}$ & $\mathbf{1 2 . 5}$ & \\
\hline Inhibition zone mm & & & & & \\
P. mirabilis & 20 & 32 & 21 & 34 & 100 \\
A. baumannii & 40 & 36 & 35 & 34 & 12.5 \\
S. saprophyticus & 25 & 22 & 18 & 13 & 12.5 \\
E. faecalis & 22 & 20 & 17 & 18 & 25 \\
\hline
\end{tabular}

MIC: Minimum inhibitory concentration. R. officinalis: Rosmarinus officinalis, P. mirabilis: Proteus mirabilis, A. baumannii: Acinetobacter baumannii,

S. saprophyticus: Staphylococcus saprophyticus, E. faecalis: Enterococcus faecalis

been ascribed to many factors, including geographical environment, genetic heritance, population density of plant in addition to physical 
Table 4: The results of several studies of essential oil yields and chemotypes of different parts of $R$. officinalis

\begin{tabular}{|c|c|c|c|}
\hline Geographical origins & Percentage of yield oil (v/w) (\%) & $\begin{array}{l}\text { R. officinalis chemotypes (major constituents) and \% of } \\
\text { terpinen-4-ol }\end{array}$ & References \\
\hline Sudan & 3 & $\begin{array}{l}\text { Bornyl acetate }(20.27 \%) \text {, caryophyllene }(13.61 \%) \text {, and } \\
\text { eucalyptol }(12.84 \%)\end{array}$ & [31] \\
\hline Lalehzar, Iran & 2.6 & $\begin{array}{l}\alpha \text {-pinene }(43.9 \%), 1,8 \text {-cineole }(11.1 \%) \text {, and } \\
\text { camphene }(8.6 \%) \text {. Also, has } 0.1 \% \text { of terpinen- } 4 \text {-ol as a } \\
\text { minor compound }\end{array}$ & [32] \\
\hline Konya, Turkey & 1.9 & $\begin{array}{l}\text { P-cymene }(44.02 \%) \text {, linalool }(20.5 \%) \text {, and } \\
\text { terpinene }(16.62 \%)\end{array}$ & [33] \\
\hline Chtouka Ait Baha, Morocco & 1.9 & $\begin{array}{l}\alpha \text {-pinene }(34.83 \%), 1.8 \text {-cineole }(28.30 \%) \text {, and other } \\
\text { components at relatively low levels: Camphor }(10.54 \%) \\
\text { and camphene }(6.21 \%)\end{array}$ & {$[34]$} \\
\hline Vienna (Austria) & 1.84 & $\begin{array}{l}1,8 \text {-cineole }(41.6 \%), \text { camphor }(17.0 \%) \text {, and } \\
\alpha \text {-pinene }(9.9 \%)\end{array}$ & [35] \\
\hline Giza, Egypt & 0.41 & Camphor (14.9\%), $\alpha$-pinene (14.9\%), and 1, 8-cineole (9\%) & [36] \\
\hline Different locations in India & - & $\begin{array}{l}\text { Camphor }(23.1-35.8 \%), 1,8 \text {-cineole }(21.4-31.6 \%) \text {, and } \\
\alpha \text {-pinene }(6.7-15.6 \%)\end{array}$ & {$[37]$} \\
\hline
\end{tabular}

Adash (-) indicate not reported. R. officinalis: Rosmarinus officinalis

and chemical characteristics of soil, growing media, and time of harvest [38,39].

The crude extracts of $R$. officinalis leaves cultivated in Baghdad, Iraq, were evaluated for their cytotoxic effect, and the results showed no hemolysis of blood cells after $24 \mathrm{~h}$ incubation at $37^{\circ} \mathrm{C}$. However, no cytotoxic effects have been shown with maximum concentration test of rosemary extracts on human erythrocytes by using well plate method.

The antibacterial effect of rosemary leaves against different species showed dose-dependent activity that is increased when the dose of extract increased on bacteria except the $P$. mirabilis had a minimum inhibition by extract effect at high concentration $(100 \mathrm{mg} / \mathrm{ml})$ and high inhibition effect at a low concentration $12.5 \mathrm{mg} / \mathrm{ml}$. The most sensitive bacteria was A. baumannii with inhibition zone $40 \mathrm{~mm}$ at high concentration.

Therefore, according to our obtained findings, the rosemary plant has good antibacterial activity against some Gram-negative and Gram-positive pathogenic bacteria. This antibacterial effect belongs to the presence of diterpeneoids and phenolic acid compounds. Therefore, it is recommended to use in an alternative medicine as a source of natural antibiotics.

\section{CONCLUSION}

Our results highlight the successful grown of rosemary in Iraq with a good quantity of rosmarinic acid and good essential oil percentage. This study also introduces Iraqi $R$. officinalis as a plant rich with camphor, terpinen-4-ol, and 1,8-cineole as major compounds of monoterpene in this plant. No cytotoxic effect of rosemary on human cell and good inhibition effect of alcoholic extract of rosemary leaves against E. faecalis, S. saprophyticus, A. baumannii, and P. mirabilis bacteria. We suggest that these isolated compounds are a suitable candidate for further clinical and pharmacological study.

\section{ACKNOWLEDGMENTS}

The authors are very grateful to Assist lecturer Mr. Zaid Mohammed for their collaboration in the achievement of this work, we offers our sincere gratitude to the Department of Pharmacognocy and Medicinal Plant, College of pharmacy, Mustansyria University, for providing the laboratory and experimenter facilities for performing this work.

\section{REFERENCES}

1. Petrovska B. Historical review of medicinal plants' usage. Pharmacogn Rev 2012;6:1-5.

2. Banjaw DT, Wolde TG, Gebre AM. Rosemary (Rosmarinus officinalis L.) variety verification trial at wondogenet, South Ethiopia. Med Aromat Plants (Los Angel) 2016;5:51-2.
3. Amar Y, Meddah B, Bonacorsi I, Costa G, Pezzino G, Saija A, et al. Phytochemicals, antioxidant and antiproliferative properties of Rosmarinus officinalis L on U937 and CaCo-2 cells. Iran J Pharm Res 2017; $16: 315$.

4. European Medicine Agency. Assessment Report on Rosmarinus officinalis L., Aetheroleum and Rosmarinus officinalis L., Folium. Committee on Herbal Medicinal Products (HMPC). No: 13613, 2009.

5. Bhatt R, Mishra N, Bansal PK. Phytochemical, pharmacological and pharmacokinetics effects of rosmarinic acid. J Pharm Sci Innov 2013;2:28-34

6. Mølgaard P, Ravn H. Evolutionary aspects of caffeoyl ester distribution in dicotyledons. Phytochemistry 1988;27:2411-21.

7. Baba S, Osakabe N, Natsume M, Yasuda A, Muto Y, Hiyoshi K, et al. Absorption, metabolism, degradation and urinary excretion of rosmarinic acid after intake of Perilla frutescens extract in humans. Eur J Nutr 2005;44:1-9.

8. Rocha J, Eduardo-Figueira M, Barateiro A, Fernandes A, Brites D, Bronze R, et al. Anti-inflammatory effect of rosmarinic acid and an extract of rosmarinus officinalis in rat models of local and systemic inflammation. Basic Clin Pharmacol Toxicol 2015;116:398-413.

9. Kumari S. Evaluation of $\alpha$-glucosidase inhibitory potential of methanolic leaf extract of Ocimum canum. Int J Pharm Pharm Sci 2018; 10:126-31

10. Luis JC, Gonzalez-Padron MY, Perez RM, Viera IF, Gonzalez FV. Rosmarinic acid: Biological, pharmacological, and in vitro plant cell culture approximation. In: Chemistry and Pharmacology of Naturally Occurring Bioactive Compounds. London: Taylor \& Francis Group; 2013. p. 471-81.

11. Bais HP, Walker TS, Schweizer HP, Vivanco JM. Root specific elicitation and antimicrobial activity of rosmarinic acid in hairy root cultures of Ocimum basilicum. Plant Physiol Biochem 2002;40:983-95.

12. Nicolai M, Pereira P, Vitor RF, Reis CP, Roberto A, Rijo P. Antioxidant activity and rosmarinic acid content of ultrasound-assisted ethanolic extracts of medicinal plants. Measurement 2016;89:328-32.

13. Kim GD, Park YS, Jin YH, Park CS. Production and applications of rosmarinic acid and structurally related compounds. Appl Microbiol Biotechnol 2015;99:2083-92.

14. Seyedemadi P, Rahnema M, Bigdeli MR, Oryan S, Rafati H. The neuroprotective effect of rosemary (Rosmarinus officinalis L.) hydroalcoholic extract on cerebral ischemic tolerance in experimental stroke. Iran J Pharm Res 2016;15:875.

15. Tavafi M, Ahmadvand H. Effect of rosmarinic acid on inhibition of gentamicin induced nephrotoxicity in rats. Tissue Cell 2011;43:392-7.

16. Akrout A, Hajlaoui H, Mighri H, Najjaa H, Jani HE, Zaidi S, et al. Chemical and biological characteristics of essential oil of Rosmarinus officinalis cultivated in Djerba. J Essent Oil Bearing Plants 2010;13:398- 411

17. Keszei A, Brubaker CL, Foley WJ. A molecular perspective on terpene variation in Australian myrtaceae. Aust J Botany 2008;56:197-213.

18. Mandal MD, Mandal S. Honey: Its medicinal property and antibacterial activity. Asian Pac J Trop Biomed 2011:1:154-60.

19. Silva MA, Silva MD, Higino JS, Pereira MS, Carvalho AD. In vitro antimicrobial activity and antiadherence of Rosmarinus officinalis 
Linn. Against oral planktonic bacteria. Rev Bras Farmacognosia 2008; 18:236-40.

20. Moreno S, Scheyer T, Romano CS, Vojnov AA. Antioxidant and antimicrobial activities of rosemary extracts linked to their polyphenol composition. Free Radic Res 2006;40:223-31.

21. Sravanthi M, Mohan GK, Suryakala G, Rani MS, Shanker K. Plant tissue culture: An alternative for production of useful secondary metabolites. J Pharmacogn Phytochem 2016;5:269.

22. Adham AN. Comparative extraction methods, phytochemical constituents, fluorescence analysis and HPLC validation of rosmarinic acid content in Mentha piperita, Mentha longifolia and Osimum basilicum. J Pharmacogn Phytochem 2015;3:130-9.

23. Craciun ME, Cretu G, Miricioiu M, Birloiu AM, Clej D, Nechifor AC. Identification, separation and quantification of rosmarinic acid from extract of orthosiphon by HPTLC. Rev Chim 2014;65:621-6.

24. Hossain MB, Rai DK, Brunton NP, Martin-Diana AB, Barry-Ryan AC. Characterization of phenolic composition in lamiaceae spices by LCESI-MS/MS. J Agric Food Chem 2010;58:10576-81.

25. Benedec D, Hanganu D, Oniga I, Tiperciuc B, Olah NK, Raita O, et al. Assessment of rosmarinic acid content in six lamiaceae species extracts and their antioxidant and antimicrobial potential. Pak J Pharm Sci 2015;28:2297-303.

26. Altintas A, Göger F, Duymuș H, Kırımer N, Bașer K. Quantitative analysis of rosmarinic acid in Rosmarinus officinalis growing in Turkey by LC-MS/MS. Planta Med 2011;77:1-2.

27. Shekarchi M, Hajimehdipoor H, Saeidnia S, Gohari AR, Hamedani MP. Comparative study of rosmarinic acid content in some plants of labiatae family. Pharmacogn Mag 2012;8:37-41.

28. Gîrd CE, Nencu I, Costea T, Duţu LE, Popescu ML, Ciupitu N. Quantitative analysis of phenolic compounds from Salvia officinalis L. leaves. Farmacia 2014;62:649-57.

29. Kikuzaki H, Nakatani N. Structure of a new antioxidative phenolic acid from oregano (Origanum vulgare L.). Agric Biol Chem 1989;53:519- 24 .
30. Akhtar MS, Hossain MA, Said SA. Isolation and characterization of antimicrobial compound from the stem-bark of the traditionally used medicinal plant Adenium obesum. J Trad Complementary Med 2017;7:296-300.

31. Elhassan IA, Osman NM, Centre C. New chemotype Rosmarinus officinalis L. (Rosemary) $R$. officinalis ct. bornyl acetate. Am J Res Commun 2014;2:232-40.

32. Jamshidi R, Afzali Z, Afzali D. Chemical composition of hydrodistillation essential oil of rosemary in different origins in Iran and comparison with other countries. Am Eurasian J Agric Environ Sci 2009;5:78-81.

33. Ozcan MM, Chalchat JC. Chemical composition and antifungal activity of rosemary (Rosmarinus officinalis L.) oil from turkey. Int J Food Sci Nutr 2008;59:691-8.

34. Mattazi NE, Farah AB, Fadil MO, Chraibi MA, Benbrahim KF. Essential oils analysis and antibacterial activity of the leaves of Rosmarinus officinalis, Salvia officinalis and Mentha piperita cultivated in agadir (Morocco). Int J Pharm Pharm Sci 2015;7:73-9.

35. Tschiggerl C, Bucar F. Investigation of the volatile fraction of rosemary infusion extracts. Sci Pharm 2010;78:483-92.

36. Soliman FM, El-Kashoury E, Fathy M, Gonaid MH. Analysis and biological activity of the essential oil of Rosmarinus officinalis L. from Egypt. Flavour Fragr J 1994;9:29-33.

37. Verma RS, Rahman L, Mishra S, Verma RK, Chauhan A, Singh A. Changes in essential oil content and composition of leaf and leaf powder of Rosmarinus officinalis cv. CIM-Hariyali during storage. Maejo Int J Sci Technol 2011;5:181-90.

38. Zewdineh D, Bizuayehu TD. Leaf essential oil and artemisinin yield of artemisia (Artemisia annua L.) as influenced by harvesting age and plantpopulation density. World J Agric Sci 2011;7:404-12.

39. Gharib F, Ghazi S, Aly H, El-Araby M, Moustafa S. Effect of soil type and water content on rosemary growth and essential oil yield. Int J Sci Eng Res(IJSER) 2016;7:183-9. 